as the real articles emit a rattle or squeak when touched with solid carbon dioxide.

It is also noteworthy that the object to be excited need not be rigidly supported. Another characteristic is the picking out of single overtones in objects of irregular shape which emit but a jangle of notes when struck with a hammer. This might be applied to find the resonances in either small pieces of machinery or in smallscale models of larger machines.

Finally, looking to the future, it is worth recording that the demonstration of the production of
Chladni figures by means of solid earbon dioxide is an excellent subject for scientific television ${ }^{5}$ since, while the patterns grow on the screen, the corresponding note is heard by the ear. The success of the demonstration is assured by the dry, warm conditions which necessarily prevail under the fierce illumination necessary for the projection.

${ }^{1}$ NATURE, 135, 475 (1935).

${ }^{2}$ Proc. Phys. Soc., 45, 101 (1933); 46, 116 (1934) ; 49, 522 (1937).

${ }^{3}$ Proc. Phys. Soc., 5), 70 (1938); 51, 831 (1939); 52, 452 (1940); 53, 35 (1941).

4 NatuRe, 143, 27 (1939).

she Listoner, 527 (1938).

\title{
CENTENARY OF W. H. HUDSON
}

\section{By H. J. Massingham}

W H. HUDSON, the centenary of whose birth W $\cdot$ is celebrated this month (see NATURE of August 9, p. 160), was unique as an interpreter of Nature, and that is perhaps the reason why he has had neither followers nor predecessors. The school of modern ornithology and natural history acknowledges no debt to Hudson; its highly specialized activities would, indeed, have been abhorrent to a naturalist who wrote "To specialize is to lose your soul". Its prophets and teachers have been Edmund Selous, Eliot Howard and the biologists, not Hudson. Nor is it possible to trace any line of descent or genealogical tree between him and such great or less dynamic names as John Evelyn, Gilbert White, Dorothy Wordsworth, Edward Jesse, Thomas Miller, Charles Watterton, Frank Buckland, Richard Jefferies, and others, all of whom are to be gathered from the 'herbarium' of the English rural tradition. If we prospect English writers who have immortalized foreign scenes like Bates, Darwin, Wallace, Belt and their kin, we shall find only a superficial resemblance between their works and the Hudsonian corpus of exotic reminiscence like "Far Away and Long Ago", "Idle Days in Patagonia", "The Purple Land", "El Ombu" and "The Naturalist in La Plata". The only exception to so general a statement is perhaps "Argentine Ornithology", written avowedly as a text-book and in conjunction with W. C. Sclater, a professed man of science. But even in this work Hudson is plainly cramped and ill at ease, while his descriptions are constantly flooding the scientific banks of classification and the presentation of strictly relevant data.

On the other hand, the problem of assessing Hudson's place in science or letters or both or neither is by no means solved by assuming, as his fellow and contemporary observers of Nature were inclined to do, that he was first an artist and only secondarily a naturalist. This was an error of the first magnitude. Hudson's contributions to our knowledge of South American fauna and flora were both extensive and profound. To say nothing of his intimate studies of Argentine and Patagonian birds, particularly in courtship, migration, social habits and melody, his masterly discoveries into the living characteristics of such pampa or desert animals as puma, vizcacha, huanaco, dolichotis, semi-domesticated cattle and horses (not to mention the feral Indian and gauchos) alone entitle him to take his place among the chieftains in the hierarchy of natural observation. His original records of English wild life were of scarcely less permanent value and novelty. Instances are numerous-I need only refếr to his accounts of Locusta viridissima in "Hampshire Days", of such rare species as the Dartford and marsh warblers, of the continued mating of starlings after the breeding season in "Birds in a Village", of the behaviour of shepherds' dogs in "A Shepherd's Life", of the perceptual senses of deer in "A Hind in Richmond Park", to his criticisms of Darwin's theory of sexual selection, and there are at least a score of further examples which reveal Hudson as a pioneer in the investigation of natural phenomena alone.

Yet it is obvious that to claim Hudson for the remembrance of posterity upon no other ground than this is to compass only a fragment of the man. Hudson was essentially a mysterious and paradoxical figure, and this central truth about him gave much handle to misunderstanding both among men of science and the general public. The latter realized his greatness so little as to ignore his enrichment both of science and literature for the first thirty years of his English life after leaving the Argentine. $\mathrm{He}$ was compelled to live in London (in the 
dingier part of Bayswater) because he could not afford to escape from it into his natural environment, which was the country, and the wilder the better. He was not recognized as of any deep significance in authorship until he was an old man, and then, as he told me himself more than once, when fame and the less straitened means that accrued from it were of little account to him. To the learned he was suspect because he mixed up natural history with religion, poetry, animism, fancy, emotion and the humanities. He would not fit in to the current definition of the arts because of his naturalism and his crusading spirit or into that of scientific analysis because such elements as vision and fantasy were considered irrelevant to it. That is the trouble of being something unique : escaping all the categories, it earns either their hostility or indifference. And it must be confessed that it is difficult to come to terms with a man who is neither one thing nor the other, but both in one, a oneness that is specifically neither.

Nevertheless, I think it is possible to arrive at a true conception of this enigmatic spirit, though without dispelling a certain mystery that clothes him and is part of the mystery of life itself. But only on one condition. It is that we should regard him not as standing apart from Nature and examining its manifestations in the detachment of subject from object, but as a being living and speaking within Nature and in an organic relation with Nature extremely difficult for modern man to comprehend. Withdrawal from Nature is the attitude of modernism, and distance in this instance lends not enchantment but diminution to the view. By looking at Hudson as a kind of human embodiment out of Nature, we are not only enabled to see him more clearly and to resolve the apparent contradictions and antitheses in his make-up, but also to enlarge our own perception of Nature itself, or, as Hudson would undoubtedly have said, of Nature herself.

The most remarkable quality of Hudson as a writer was his articulate primitiveness. This went very deep, and was by no means confined to his habitual and entirely unsophisticated preference for the wildness in Nature. He wrote, if I may be pardoned the apparent antimony, as a richly cultivated wild man, and to an extraordinary degree he shared certain characteristics of primitive man which in the most natural way he embodied into his writings. The animistic tendency is one, closely allied with the mythopœic and with story-telling. Hudson could scarcely write a page without bringing some tale into it, tales not only of fact but also of invention, not only of the concrete, but also of the fantastic, and the curious thing is that his reader is not in the least jolted by their seeming incompatibility. Myth and actuality were strangely blended, and his anthropomorphic bent (heinous to the scientific mentality !) was just as 'real' in him as were his chronicles of animals or peoples, whose bona fides nobody would think of doubting.

Yet in other aspects Hudson was a good deal more modern than the moderns. His vision of Nature--and we are bound to speak of it as suchwas consciously pantheistic, often expressing itself in exalted (though always simple) idiom and imagery that remind us of the much more intricate seventeenth-century 'metaphysicals'. His idea of man's place in Nature, utterly contrary to Huxley's, as gathering to a point the joy and exuberance of natural life and through it finding contact with the unseen world, as drinking deep of the life of Nature but observing a royal impartiality towards its phenomena and refraining from interference with its balances and interdependences, this mental approach is a philosophical rendering of a primitive feeling. Hudson loathed all human rapacity towards Nature, but disdained the sentimentalism of reproaching "the cruelty of Nature" in raptorial bird or beast. His mind was entirely estranged from that of civilization because its home was both behind and beyond it.

The Russian lecturer, Nicolas Berdyaev, directs a searching criticism against the modern theory of progress on the ground that it disintegrates time into past, present and future, which are spectral in the sense that each devours the other. Hudson's work is an apt illustration of these three divisions of time in a mutual and non-destructive relation to one another. To Hudson the primitive past was the deepest source of his inspiration, and through it he envisaged a future of the relations between man and Nature which would enshrine their reconciliation. His most famous book, "Far Away and Long Ago", reveals a more personal fusion between boyhood and old age (it was written when he was seventy-six) inexplicable from the point of view of an enkindled memory alone. This minutely detailed record of his childhood on the Argentine pampas is perhaps the most astonishing example of re-animation in our literature. The entire wild scene with its people, its flowers and animals, its effects of light and shade, together with his. own sentiments and adventures and reactions, are presented as a living whole with such immediacy that the gaps both of time and space are annihilated. Hudson senex evokes a Hudson puer not of yesterday, but contained within the present, and there is no other word for this but mystery.

A passage in "The Land's End" illuminates this merging between past and present, boyhood and age, beginnings and ends, the primeval and the more-than-civilized from another and yet stranger aspect. One of a party of grey pilgrims looks over 
the sea from the end of all the land, the ancient Bolerium :

"He sees only what his heart desires-a silent land of rest. No person will greet him there, he will land and go up alone into that empty and solitary place, a still grey wilderness, extending inland and upward hundreds of leagues, an immeasurable distance, into infinity. . . . The sky in that still land is always pale grey-blue in colour, and the earth, too, is grey like the rocks, and the trees have a grey-green foliage-trees more ancient in appearance than the worn granite hills. ... There he will remain motionless and contented for ever in that remote desert land where is no sound of singing bird nor of running water nor of rain or wind in the grey ancient trees. ..."

This "illimitable wilderness" is antediluvian and post mortem, the beyond and the uncreate; it is the Land's End and it is Patagonia that he loved even better than his estancia-home of La Plata, where the bright birds sang in the peach-grove; it is the goal of age and the longing of youth; it is intensely symbolic and yet an actual scene. It is all these things in one, and it is thus a conquest of time in total opposition to the modern "conquest of nature" and enslavement to a time arbitrarily sliced up into three divisions.

We shall never understand Hudson unless we see him bathed in this mysterious light, unless we look for him within the heart of Nature where the visionary is inseparable from that which is observed, beauty and romance are fused with an objective natural history and where to see, to know, and to feel are a triune experience. Only one link in the chain of integration is missing, and that is the craft of husbandry, where Nature and man meet on equal terms. But the primitive wildness that was the heart of Hudson did not permit him to sur- mount the last impediment to a final synthesis. Yet in closing the division between natural truth and poetic beauty without doing violence to either, he, the primitive, must surely rank among the very greatest of modernists. The war of aggression against Nature by means of the machine and the combine would have been profoundly antipathetic to both these elements of his complex being.

As a 'stylist' Hudson is impossible to anatomize. His is not a literary way of writing at all, still less has it any affinity with modern cultism in selfexpression. He wrote just as he thought, narrated, described, and speculated-namely, as a child of Nature raised to a high degree of self-consciousness. His manner of writing, that is to say, is the natural manner of growth in the plant, of flight in the bird, and of movement in the wind or the sea. There are no spot-lights in metaphor or imagery, nor is there any sense of manufacture in the structure of the sentences. At times a page will be a flat monotone like a dull day; at others like a spring morning, when the dew is on the spray. His argument, whatever it may be, unfolds itself like a vine tendril or a clematis shoot making its unobtrusive way into the sunshine. Or the pace quickens and a tuft of bright-coloured flowers appears on the green background. His style is thus a method of articulation in perfect harmony both with his subject and his own mystical and intuitive contact with the childhood of mankind. The man who identified himself with all creation and through it felt the touch of the unseen conveyed into his writing the sense of a lost world "where the rose has got Perfume that on earth is not", an Adamite paradise of Nature which has haunted the imagination of the more sensitive among men since the days of Hesiod.

\section{O B I T UAR IES}

Prof. A. J. Clark, F.R.S.

By the death, on July 30, of Prof. A. J. Clark, at the age of fifty-five, pharmacology has lost its leading exponent in Great Britain. He was born in Somerset in 1885, went to Bootham School, and obtained one of the first major entrance scholarships in science at King's College, Cambridge. After an unexpectedly brilliant performance in the Tripos, he went as a student to St. Bartholomew's Hospital, London, and took the degree of M.B. in 1910. $\mathrm{He}$ worked with Zunz for a time, and then became Cushny's assistant at University College, London. He was professor of pharmacology in Cape Town, and then succeeded Cushny, first at University College, and then in Edinburgh, where he had been since 1926.
During the War of 1914-18 Clark served in the R.A.M.C. as a captain, and was awarded the M.C. During the present War it was natural that he should be appointed physiological and medical adviser to General Headquarters. $\mathrm{He}$ went out to France in 1940 as a lieutenant-colonel just in time to play his part in the withdrawal of the British forces.

He married Beatrice Powell, daughter of the late Dr. Hazell of Cape Town, in 1919, and had two sons and two daughters.

Clark's restless energy and wide knowledge were evident both in his work and in his conversation, and were always available for the assistance of his colleagues, but his general knowledge was also great, and his advice was valued by all. He was a member 